\title{
Hakulausekkeen muodostamisen vaikeus - nuorten ja opettajien taidot testissä
}

\author{
Loretta Saikkonen \\ Turun yliopisto \\ lorgal@utu.fi \\ https://orcid.org/0000-0002-9818-4156
}

\begin{abstract}
The research objective was to find out Finnish 12-22-year-old students' ( $\mathrm{N}=3222)$ and primary, secondary and high school teachers' $(\mathrm{N}=573)$ information retrieval skills in forming a search phrase and using search operators. The results indicate that the skills for defining search queries among youths and teachers are insufficient. Teachers performed better in forming a search phrase than the students, even though high school students succeeded better than over 45 -year-old teachers. Male teachers performed significantly better in forming a search phrase than female teachers. Half of the teachers and a fifth of the students used search operators in their search phrases. Overall, the search phrases created by the students and teachers were too simple and did not cover the entire assignment. Every tenth of the students tried to create a web address instead of a search phrase and some students wrote requests or questions to the search engine. On the basis of these students' mistakes in the search phrase task, one can state that students need more training especially on forming comprehensive search phrases, using typical search operators, and understanding the functions of search engines.
\end{abstract}

Asiasanat: tiedonhaku; hakulauseke; hakusanat; hakuoperaattorit; opettajat; nuoret

Tiedonhausta on tullut tärkeä osa jokapäiväistä elämäämme, ja älypuhelimet mahdollistavat tiedonhakuprosessin missä ja milloin tahansa. Informaation hankinnan ja sen hyödyntämisen taidot ovat tulleet entistä tärkeämmiksi, ja 
myös kouluoppimisessa pyritään enenevissä määrin hyödyntämään ilmiöpohjaista, tutkivaa ja ongelmalähtöistä oppimista tietoa toistavan oppimisen sijaan (ks. Opetushallitus, 2014, 2015). Perusopetuksen opetussuunnitelmassa (Opetushallitus, 2014) oppilailta edellytetään kykyä itsenäiseen opiskeluun, tiedonhankintaan, informaation tulkintaan ja luotettavuuden arviointiin sekä hankitun informaation työstämiseen kulloistenkin tavoitteiden mukaan. Tähän liittyvä taito on kunkin tehtävän tai ongelman kannalta olennaisen informaation löytäminen ja sen soveltaminen tehtävän edellyttämällä tavalla. Opettajat eivät välttämättä ole tietoisia siitä, millaisia ongelmia oppilaat kohtaavat yrittäessään etsiä tarvitsemaansa tietoa Internetistä.

Suurin osa kulloinkin tarvitsemastamme informaatiosta on koko ajan saatavillamme, vain muutaman klikkauksen päässä. Nykyään oppilaat voivat etsiä ja hankkia sellaista tietoa, jota ei löydy oppikirjoista tai kirjastosta. Tiedonhaku ei kuitenkaan aina ole yksinkertaista; Informaation etsijän on osattava valita sopiva tiedonhakukanava, hallittava erilaisia hakutermejä, osattava muodostaa tilanteeseen sopiva hakulauseke sekä kyettävä muokkaamaan hakusanoja uudelleen, mikäli haku ei tuota haluttua tulosta. Informaatiota on entistä helpommin ja nopeammin saatavilla, mutta sitä leimaa ristiriitaisuus, hajanaisuus ja epävarmuus. (Henry, 2006; Leu, Kinzer, Coiro, \& Cammack, 2004.; OECD, 2015)

Ennen Internetiä tiedonhakijat olivat yleensä informaatioalan ammattilaisia, jotka hakivat tietoa joko muille, kuten kirjastonhoitajat kirjaston asiakkaille, tai itselleen, kuten jonkin alan ammattilaiset alansa tietojärjestelmistä. Nykyään kuka tahansa voi hakea lähes mitä tahansa informaatiota Internetistä ilman minkäänlaista tiedonhakukoulutusta. Nykyään tiedonhaussa käytetäänkin laajasti erilaisia tiedonhakustrategioita ja päädytään vaihteleviin sekä usein myös ristiriitaisiin hakutuloksiin. Lisäksi tiedonhakutilanteissa ollaan nykyisin yleensä yksin - jokaisen on osattava muotoilla hakulausekkeensa itse, sen sijaan, että kysyisi neuvoa koulutetulta tiedonvälittäjältä (vrt. kirjastonhoitaja). (Knight \& Spink, 2008.)

Lapsilla ja nuorilla on aiemmissa tutkimuksissa todettu olevan vaikeuksia hakulausekkeiden muodostamisessa (esim. Kaarakainen \& Saikkonen, 2017; Kammerer \& Bohnacker, 2012; Kiili, 2012; Kiili, Laurinen, \& Marttunen, 2008, 2009; van Deursen, Görzig, van Delzen, Perik, \& Stegeman, 2014; van Deursen \& van Diepen, 2013; Walraven, Brand-Gruwel, \& Boshuizen, 2008). Heillä on vain vähän aiempaa tiedonhakukokemusta, heidän käyttämänsä hakusyntaksit eivät ole kehittyneitä, he ovat kärsimättömiä tiedonhakuprosessin suhteen ja tekevät kirjoitusvirheitä (Jean ym., 2015; Walraven ym., 2008). Esimerkiksi van Deursenin ym. (2014) tutkimuksessa hollantilaisten alakoululaisten $(\mathrm{N}=76)$ yleisin keino informaation hankintaan oli kirjoittaa annettu kysymys kokonaisuudessaan hakukenttään. Ne, jotka eivät kirjoittaneet koko kysymystä hakukenttään, 
käyttivät yleensä ainoastaan yhtä hakusanaa ja hakusanojen määrittely oli heille hankalaa. Alakoululaiset tekivät myös paljon kirjoitusvirheitä ja korjasivat niitä vain harvoin. (van Deursen ym., 2014.) Lisäksi van Deursenin ja van Diepenin (2013) tutkimuksessa yksikään 11-17-vuotiaiden nuorten $(\mathrm{N}=54)$ laatimista hakulausekkeista ei sisältänyt hakuoperaattoreita (Booleans), kuten esimerkiksi lainausmerkkejä, ja lähes puolet hakulausekkeista oli liian yleisiä tehtävänantoon nähden.

Large, Beheshti ja Rahman (2002) havaitsivat tutkimuksessaan, että vaikka 11-12-vuotiaiden tyttöjen ja poikien $(\mathrm{N}=53)$ tiedonhakutaidot olivat suunnilleen samantasoiset, tiedonhakutavat erosivat sukupuolten välillä: pojat käyttivät vain yhtä hakusanaa useammin kuin tytöt, ja tytöt käyttivät poikia useammin useita hakusanayhdistelmiä. Kammererin ja Bohnackerin (2012) tutkimuksessa, suurin osa testatuista 8-10-vuotiaista $(\mathrm{N}=21)$ käytti luonnollista kieltä (naturallanguage queries) etsiessään tietoa kenguruista (esim. "Onko kaikilla kenguruilla pussi?”). Luonnollisen kielen hakulausekkeet johtivat tämän ikäisillä muita hakulauseketyyppejä useammin toivottuun lopputulokseen: lähes kaikki, jotka käyttivät luonnollisen kielen hakulausekkeita, ratkaisivat ainakin yhden testissä annetuista tehtävistä, kun vastaava onnistumisprosentti niillä, jotka käyttivät hakulausekkeissaan erillisiä hakusanoja, oli hieman alle kaksi kolmasosaa. Hakiessaan tietoa yksittäisillä hakusanoilla, lapset yleensä kirjoittivat hakukenttään yhden tai kaksi epäspesifiä hakusanaa, jolloin hakutulokset eivät tuottaneet etsittyä informaatiota. (Kammerer \& Bohnacker, 2012.)

Kiilin (2012) väitöstutkimuksessa vain harva lukiolainen osasi rajata hakukyselyt tarkoituksenmukaisesti. Lisäksi heillä oli vaikeuksia ymmärtää, miten hakukoneet toimivat sekä säädellä ja suunnitella omia hakutoimintojaan. Tiedonhakuongelmat näyttivät kasautuvan tietyille opiskelijoille, jotka toistivat tehottomia hakukyselyitä yhä uudestaan. Lisäksi opiskelijoilla oli usein vääristynyt kuva itsestään tiedonhakijoina: he luottivat taitoihinsa silloinkin, kun ne olivat heikot. (Kiili, 2012; Kiili ym., 2008, 2009.)

Myös opettajien tiedonhakutaidot ja niihin liittyvät käsitykset on aiemmissa tutkimuksissa todettu puutteellisiksi (ks. esim. Kaarakainen \& Saikkonen, 2017; Muhonen, Kaarakainen, \& Savela, 2015; Ojaranta, 2011). Kaarakaisen ja Saikkosen (2017) tutkimuksessa Internetin hakupalveluiden, sosiaalisen median palveluiden ja oman sisällön tuottamiseen käytettävien työvälineiden käyttökokemuksen todettiin edistävän opettajien tiedonhakutaitoa. Vastaavasti vähäinen teknologioiden käyttökokemus yhdistyi aineistossa heikkoihin taitoihin. Myös Hargittain ja Shaferin (2006) tutkimuksessa parhaiten tiedonhaussa menestyivät runsaasti tietokoneiden käyttökokemusta omaavat aikuiset. Tannin (2012) tutkimuksessa selvisi, että opettajankoulutuksen aikana opittuja tiedonhakutaitoja on vaikeaa opettaa oppilaille käytännössä. Aineenopettajaopiskelijat koki- 
vat, ettei heillä ole keinoja tai välineitä, joilla korjata oppilaiden tiedonhakutaidoissa esiintyviä puutteita.

Aiemmissa, samalla testillä tehdyissä, tutkimuksissa (Kaarakainen \& Saikkonen, 2015, 2017) niin suomalaisnuorten kuin heidän opettajiensakin tiedonhakutaidot todettiin varsin puutteelliseksi etenkin hakulausekkeen muodostamisen osalta. Koska hakulausekkeiden muodostamisen vaikeus kävi näissä tutkimuksissa niin vahvasti ilmi, tämän tutkimuksen tavoitteena on tarkastella hakulausekkeiden muodostamista seikkaperäisemmin analysoimalla kaikki 12-22vuotiaiden nuorten $(\mathrm{N}=3222)$ ja opettajien $(\mathrm{N}=573)$ muodostamat hakulausekkeet virhetyypin, kielivalinnan, sanamäärän ja hakuoperaattoreiden käytön mukaan. Tutkimus pyrkii vastaamaan seuraaviin tutkimuskysymyksiin:

1. Millaisia hakulausekkeita nuoret ja opettajat muodostavat?

a) Minkä pituisia hakulausekkeet ovat ja millaisia hakusanoja niissä käytetään?

b) Millaisia virheitä tai puutteita hakulausekkeissa ilmenee?

c) Miten hakulausekkeissa käytetään hakuoperaattoreita?

2. Miten hakulausekkeen muodostamisen taidot ja tavat eroavat sukupuolen ja kouluasteen mukaan sekä opettajien ja nuorten välillä?

Tutkimus lisää ymmärrystä siitä, millaisia hakulausekkeita nuoret ja heidän opettajansa muodostavat annetussa tiedonhakutilanteessa, ja mitä asioita nuorille tulisi hakulausekkeisiin liittyen opettaa, jotta he jatkossa löytäisivät tarvitsemansa informaation helpommin Internetistä.

\section{Tutkimusmenetelmä}

Turun yliopiston Koulutussosiologian tutkimuskeskuksessa kerättiin vuosina 2014-2015 tutkimusaineistoa 12-22-vuotiaiden nuorten $(\mathrm{N}=3222)$ sekä peruskoulun ja lukion opettajien $(\mathrm{N}=573)$ tieto- ja viestintätekniikkataidoista. Testaukset toteutettiin pääasiassa Varsinais-Suomen yläkouluissa, lukioissa ja ammatillisissa oppilaitoksissa selainpohjaisen kysely- ja testiympäristön avulla. Nuorten testaustilanteet olivat valvottuja, eikä testatuilla ollut mahdollisuutta hyödyntää Internetiä tehtävien ratkaisemiseen. Testaukset tehtiin oppilaitoksissa luokka tai koulu kerrallaan. Tutkimusaineistoon kuuluvista 3222 nuoresta poikia on 52 prosenttia $(n=1671)$ ja tyttöjä 48 prosenttia $(n=1550)$. Yläkoululaisia on 40 prosenttia $(n=1279)$, lukiolaisia 32 prosenttia $(n=1032)$ 
ja ammatillisten oppilaitosten opiskelijoita 28 prosenttia $(n=911)$. Nuorten keskiarvoikä on 15,9 vuotta.

Opettajien $(\mathrm{N}=573)$ taidot testattiin samalla testillä kuin nuortenkin. Opettajien testaukset toteutettiin organisaatioittain. Valtaosa osallistuneista 33 organisaatioista sijaitsee Etelä- ja Länsi-Suomessa. Mukana on tasaisesti sekä muutaman opettajan maaseutukouluja että yli 50 opettajan kaupunkialueilla sijaitsevia oppilaitoksia. Oppilaitokset osallistuivat tutkimukseen rehtorin tai sivistystoimen johtajan päätöksellä. Kaikissa aineistoon sisältyvissä opettajaorganisaatioissa vastausprosentti oli yli 74 . Tutkimusaineistoon kuuluvista 573 opettajasta miehiä on 28 prosenttia $(n=160)$ ja naisia 72 prosenttia $(n=413)$. Alakoulujen opettajia on 298, yläkoulujen opettajia 225 ja lukioiden opettajia 83. Lukumäärät ylittävät koko aineiston opettajien yhteismäärän, koska osa opettaa useammalla kouluasteella. Aineiston opettajien keski-ikä on 45 vuotta $(25-64 \mathrm{v})$.

Tässä tutkimuksessa analysoidaan laajaan tieto- ja viestintätekniikkatestiin (ks. esim. Muhonen ym., 2015) sisältyvän hakulauseketehtävän pisteitä ja avovastauksia. Hakulauseketehtävän tehtävänanto kuului seuraavasti: "Tehtävänäsi on hakea Euroopan avaruusjärjestö ESAn sivustolta (http://www.esa.int) lapsille tarkoitettua sivua taivaankappale Plutosta. Minkälaisella hakulausekkeella haet sivua ja rajaat piirroshahmot pois hakutuloksista?". Tehtävästä oli mahdollista saada yhteensä kolme pistettä: yksi site-operaattorin oikeasta käytöstä, yksi rajauksesta (NOT-operaattori) ja yksi oikeista hakusanoista (esim. lapsi 0,5 $\mathrm{p}$ ja pluto 0,5 p). Oikeiksi vastauksiksi hyväksyttiin sekä suomen- että englanninkieliset termit. Hakusanoja arvioitiin käsitetasolla eli pisteytyksessä painotettiin oikeiden pääkäsitteiden löytämistä (missä muodossa tahansa) merkkijonotason arvioinnin sijaan (ks. Järvelin \& Sormunen, 2010, ss. 14-16). Rajauksessa tärkeintä oli osata hyödyntää NOT-operaattoria oikein. Tehtävässä sallittiin jonkin verran epätarkkuuksia, sillä nykyaikaiset Internetin hakukoneet ovat kehittyneet siten, etteivät ne edellytä syntaksiltaan täysin eksakteja hakulausekkeita.

Tehtävänannossa pyrittiin mahdollisimman autenttiseen vaikutelmaan, joten vastauksessa tarvittavat hakuoperaattorit käyttöesimerkkeineen annettiin tehtävään kuuluneessa ohjeessa (ks. kuva 1), joka oli koostettu Googlen suomenkielisestä haun tarkentamisen ohjeesta (vrt. Google, 2014) ${ }^{1}$. Testattavat eivät voineet kokeilla antamiaan hakulausekkeita, eivätkä siten tarkentaa niitä saamiensa

1 Lähteenä käytetyn ohjeen (Google, 2014) epätarkasti ja osin virheellisesti muotoiltuja sanamuotoja on myöhemmin korjattu hakukoneen uudempiin hakuohjeisiin. Näitä korjauksia ei voitu testitehtävään tehdä, koska testaukset oli jo toteutettu. Tästä ei kuitenkaan aiheutunut testattaville pisteiden menetyksiä. Ohjeissa puhutaan esimerkiksi NOT-operaattorin kohdalla virheellisesti väliviivasta miinusmerkin sijaan. Näin ollen NOToperaattorin oikeasta käytöstä sai täydet pisteet viivan pituudesta huolimatta. 


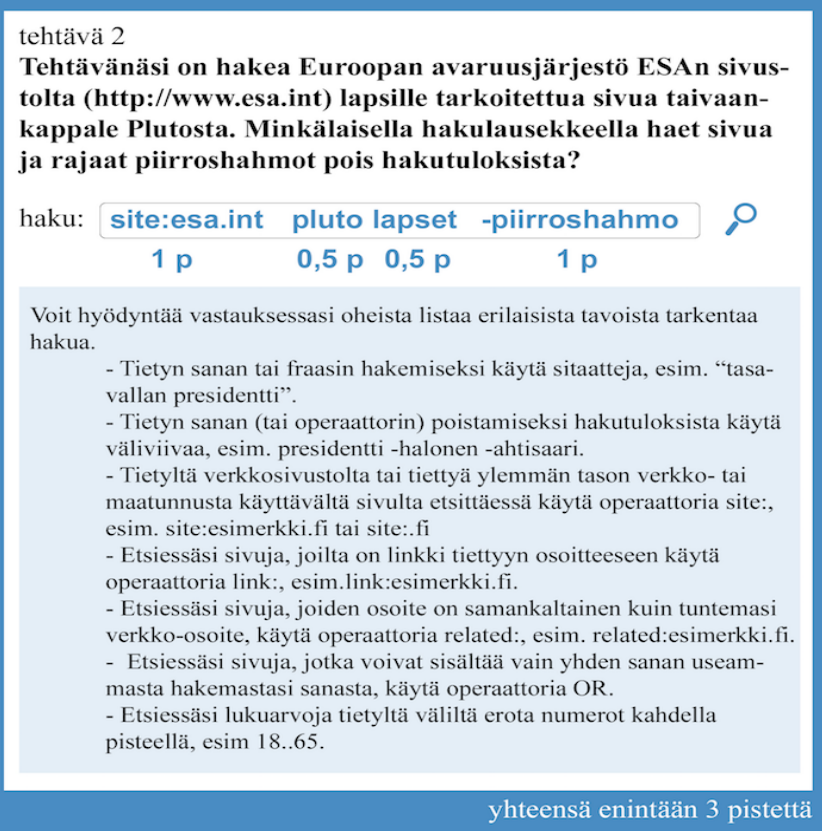

Kuva 1: Hakulauseketehtävä ja esimerkki oikeasta vastauksesta hakukentässä.

hakutulosten perusteella, vaan heidän tuli muotoilla hakulauseke kerralla kattavaksi ja tehtävänannon mukaisesti rajatuksi. Tämä ymmärrettävästi aiheuttaa sen, että testitilanne ja -tehtävä eroavat olennaisesti käytännön tiedonhakutilanteesta, jossa hakulauseketta usein muokataan saatujen hakutulosten perusteella ja lopullinen kussakin tilanteessa toimiva hakulauseke muotoutuu kokeilujen kautta.

Hakulauseketehtävässä puuttuvia eli tyhjiä vastauksia oli nuorilla 451 ja opettajilla 56, ja ne jätettiin tarkastelun ulkopuolelle. Näin ollen hakulausekkeiden luokittelussa analysoitiin 2771 nuorten ja 517 opettajien hakulauseketta pisteyttämällä ja luokittelemalla ne yksitellen ennalta määriteltyjen kriteereiden mukaan. Aluksi hakulausekkeet pisteytettiin asteikolla o-3 ja luokiteltiin aineistolähtöisesti kuuteen kategoriaan: (1) oikea tai lähes oikea vastaus (2,5-3 p), (2) liian yksinkertainen hakulauseke, (3) hakuoperaattoreiden puutteellinen tai virheellinen käyttö, (4) verkko-osoitteen muodostaminen hakukenttään, (5) kysymyksen tai pyynnön esittäminen hakukoneelle sekä (6) muu vastaus (eli tehtävään liittymätön vastaus tai "en tiedä" -vastaus). Joihinkin hakulausekkeisiin olisi sopinut useampi luokitus, mutta luokittelu ratkaistiin valitsemalla aina heikoin vaihtoehto. Jos jokin hakulauseke esimerkiksi oli liian yksinkertainen ja siitä puuttui hakuoperaattorien käyttö, luokiteltiin se luokkaan "liian yksin- 
kertainen hakulauseke". Pisteytyksessä ja hakulausekkeiden luokittelussa käytettiin kahta tarkastajaa ja yhteisiä pisteytyskriteerejä pisteytyksen luotettavuuden lisäämiseksi. Tätä artikkelia varten hakulausekkeet luokiteltiin yksitellen myös kielen (suomi/englanti), sanamäärän ja hakuoperaattoreiden määrän mukaan. Näissä luokitteluissa käytettiin vain yhtä luokittelijaa, koska luokat ovat selkeät; sanamäärät, kielen ja hakuoperaattoreiden määrän voi luokitella vain yhdellä tavalla.

\section{Tulokset}

\section{Hakulausekkeiden pisteytys ja sanamäärä}

Hakulauseketehtävässä oli mahdollista saada kolme pistettä. Niin opettajat (ka 0,93) kuin nuoretkaan $(\mathrm{ka} 0,67)$ eivät saavuttaneet keskimäärin edes kolmasosaa tarjolla olleista pisteistä, siitä huolimatta että tarvittavat hakuoperaattorit oli annettu tehtävässä. Lukiolaiset saivat keskimäärin 0,90 pistettä yltäen näin lähes opettajien tasolle keskiarvopisteissä, kun yläkoululaiset saivat tehtävästä keskimäärin vain hieman yli puoli pistettä $(0,54)$. Tyttöjen ja poikien keskiarvopisteissä ei ollut eroa. Sen sijaan miesopettajat pärjäsivät hakulausekkeen muodostamisessa naisopettajia tilastollisesti merkitsevästi paremmin (miesopettajien ka 1,13 ja naisopettajien ka 0,85, p-arvo: 0,0oo). Parhaiten hakulausekkeen muodostamisessa pärjäsivät nuorimmat eli alle 36 -vuotiaat opettajat ( $k a 1,25)$, jonka jälkeen keskiarvopisteet laskivat tasaisesti yli 55-vuotiaiden opettajien keskiarvopisteiden ollessa enää o,67. On kuitenkin todettava, että vanhimmatkin opettajat pärjäsivät tehtävässä keskimäärin kaikenikäisiä nuoria paremmin tai ainakin yhtä hyvin (yli 55-vuotiaat saivat samat keskiarvopisteet kuin nuoretkin), vaikkakin lukiolaisten keskiarvopisteiden tasolle ylsivät vain alle 45 -vuotiaat opettajat.

Peräti 80 prosenttia nuorista ja 71 prosenttia opettajista käytti hakulausekkeessaan vain 1-3 sanaa. Yleisin sanamäärä oli sekä nuorilla (38\%) että opettajilla (36 \%) kaksi sanaa. Hakuoperaattorimerkkejä (esim. site:, oR, -) ei laskettu sanoiksi. Täydet pisteet sai esimerkiksi näillä hakulausekkeilla: site:esa.int pluto lapset -disney tai plutosta lapsille -piirroshahmot site:esa.int, mikä tarkoittaa, että oikeaan vastaukseen tarvittiin vähintään neljä sanaa. Opettajilla ja nuorilla oli saman verran yli kolmesanaisia hakulausekkeita ( $27 \%$ ), yläkoululaisilla vain 16 prosenttia ja ammattikoululaisilla 17 prosenttia. Tehtävästä saadut keskiarvopisteet nousivat oletetusti sanamäärän mukaan.

Yksisanaisia hakulausekkeita oli nuorilla hieman yli joka kymmenennellä ja opettajilla seitsemällä prosentilla. Poikien hakulausekkeista 15 prosenttia oli 


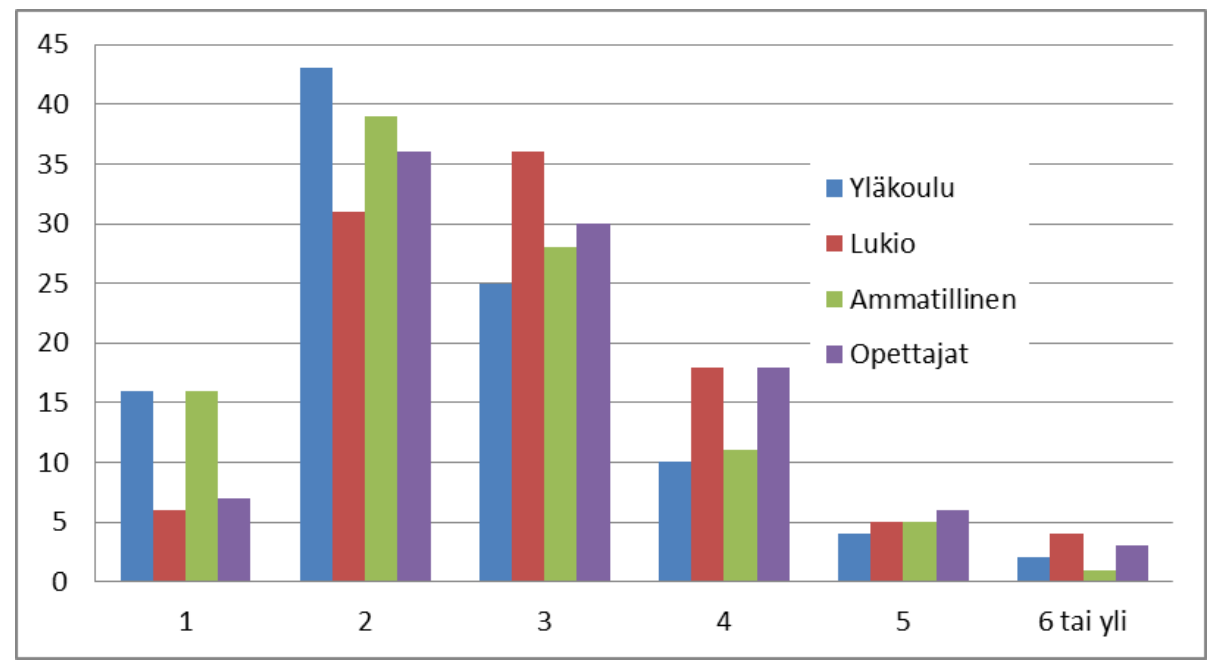

Kuva 2: Sanamäärät nuorten ja opettajien muodostamissa hakulausekkeissa (\%)

yksisanaisia ja tyttöjen lausekkeista kymmenesosa. Nuorten yksisanaisten hakulausekkeiden hakusanana oli useimmiten Pluto. Yläkoululaisten hakulausekkeista valtaosassa ( 59 \%) oli vain yksi tai kaksi sanaa. Myös ammattiopiskelijoiden hakulausekkeista yli puolet oli korkeintaan kaksisanaisia. Lukiolaisilla taas suurin osa (63 \%) hakulausekkeista oli vähintään kolmisanaisia. (Kuva 2.)

Nuorista kaksi kolmesta kirjoitti hakulausekkeensa suomeksi ja kolmannes englanniksi. Opettajista puolet kirjoitti hakulausekkeensa englanniksi. Hakulausekkeissa kaksi usein toistuvaa sanaa Pluto ja ESA ovat kansainvälisiä. Jos hakulausekkeessa oli näistä vain jompikumpi tai molemmat sanat, eikä mitään muuta, jonka perusteella kielen olisi voinut määrittää, hakulauseke luokiteltiin englanninkieliseksi. Valtaosa (6o \%) nuorten englanninkielisistä hakulausekkeista olikin 1-2-sanaisia. Vastaavasti suomenkielisistä hakulausekkeista 40 prosenttia oli alle kolmesanaisia. Englanninkieliset hakulausekkeet olivat siis yleisesti ottaen yksinkertaisempia kuin suomenkieliset. Pojat kirjoittivat hakulausekkeensa tyttöjä useammin englanniksi. Kouluasteella ei ollut juurikaan yhteyttä hakulausekkeen kielivalintaan.

\section{Hakulausekkeiden puutteet}

Täydet kolme pistettä sai, jos osasi muodostaa tehtävänannon mukaisen eli kattavan ja syntaksiltaan oikeanlaisen hakulausekkeen, jossa molempia tarvittavia hakuoperaattoreita (site: ja NOT/-) oli käytetty oikein. Täysin oikean (3 p) vastauksen antoi o,8 prosenttia nuorista ja kaksi prosenttia opettajista. Mikäli ha- 


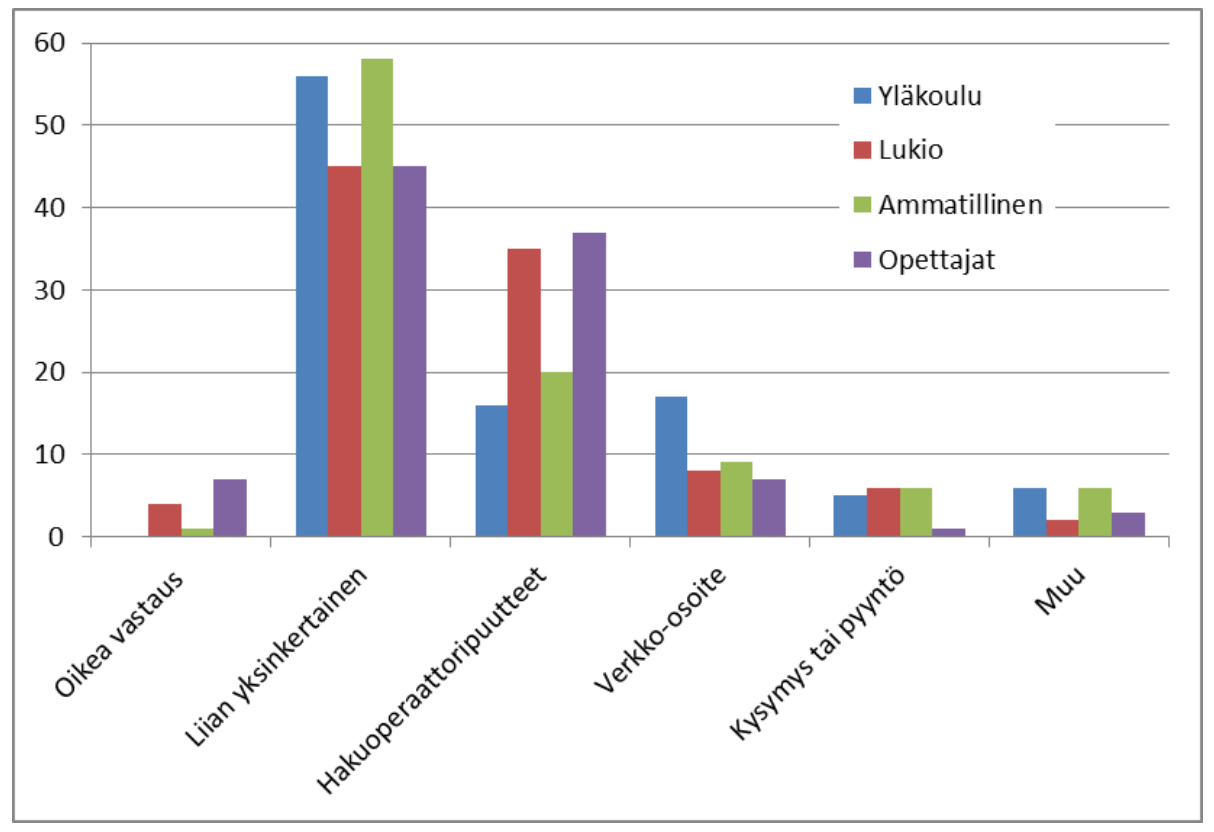

Kuva 3: Opettajien ja nuorten hakulausekkeiden tyypittely nuorten kouluasteen mukaan (\%)

kusana lapsi puuttui, mutta molempia hakuoperaattoreita oli käytetty oikein, tehtävästä sai 2,5 pistettä ja pääsi hakulausekkeiden tyypittelyssä kategoriaan oikein tai lähes oikein. Oikean tai lähes oikean vastauksen antoi nuorista kaksi prosenttia ja opettajista seitsemän prosenttia. Loput 98 ja 93 prosenttia vastauksista olivat siis jollain tapaa virheellisiä tai puutteellisia, ja nämä hakulausekkeet luokiteltiin viiteen kategoriaan virhetyypin mukaan (ks. kuva 3 ).

Liian yksinkertaisen hakulausekkeen muodosti hieman yli puolet ( $53 \%$ ) nuorista ja vähän alle puolet (45\%) opettajista. Hakuoperaattoreiden puutteellista tai virheellistä käyttöä oli neljäsosalla nuorista ja 37 prosentilla opettajista. Hakulausekkeen sijaan verkko-osoitteen yritti muodostaa joka kymmenes nuori ja seitsemän prosenttia opettajista. Kysymyksen tai pyynnön hakukoneelle esitti kuusi prosenttia nuorista ja vain sadasosa opettajista. Tehtävään liittymättömiä tai en tiedä -vastauksia oli sekä opettajilla että nuorilla alle viisi prosenttia vastauksista. Poikien ja tyttöjen välillä ei ollut juurikaan eroavaisuuksia hakulausekkeiden tyypittelyssä. Seuraavissa alaluvuissa tarkastellaan näitä viittä virhetyyppiä nuorten ja opettajien muodostamien hakulauseke-esimerkkien avulla. 


\section{Liian yksinkertaiset hakulausekkeet}

Yläkoululaisten ja ammattikoululaisten hakulausekkeista liian yksinkertaisia oli yli puolet ja lukiolaisten sekä opettajien hakulausekkeista 45 prosenttia (ks. kuva 3). Nämä hakulausekkeet olivat yleensä yksi- tai kaksisanaisia, eikä niissä ollut käytetty hakuoperaattoreita.

Pluto lapset (tyttö, ammatillinen oppilaitos)

ESA lapsille (poika, lukio)

Joskus yksinkertainen hakulauseke voi olla tarkoituksenmukainen ja säästää aikaa ja vaivaa, mutta tässä tehtävässä yksinkertaiset hakulausekkeet eivät tuota toivottua hakutulosta, sillä sanalla Pluto on kaksi merkitystä: se voi olla joko Disneyn koirahahmo tai taivaankappale. Kun yllä olevan sitaatin hakulauseketta pluto lapset kokeiltiin Googlessa, ensimmäiselle hakusivulle tuli Plutoaiheisia lastenohjelmia ja tuotteita (leluja ja vaatteita Pluto-koiran kuvilla) sekä pari astrologia-aiheista sivua, joissa puhuttiin tähtikuvioiden merkityksestä lasten elämässä. Hakusanoilla ESA lapsille yksikään hakukoneen etusivun hakutuloksista ei liity planeettoihin, vaan vie Esa-nimisistä henkilöistä kertoville sivuille.

Seuraavissa hakulausekesitaateissa nuoret ovat yrittäneet rajata Disneyhahmosta kertovat sivut pois siinä kuitenkaan onnistumatta, sillä hakutulokset antavat pelkästään Pluto-koirasta kertovia hakutuloksia etusivulle.

Pluto ei koira (poika, ammatillinen oppilaitos)

pluto epä-koira (poika, yläkoulu)

Osa liian yksinkertaisista hakulausekkeista oli aihepiiriltään niin laajoja, että on vaikea ymmärtää, miten testattavat ovat ajatelleet niiden johtavan tehtävässä pyydetylle tarkasti määritetylle sivulle.

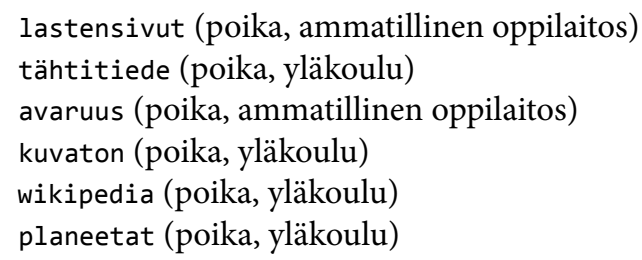

\section{Hakuoperaattoreiden puutteellinen tai virheellinen käyttö}

Mikäli hakulauseke ei ollut liian yksinkertainen, mutta siinä ei ollut käytetty tehtävässä pyydettyjä hakuoperaattoreita tai niitä oli käytetty väärin, hakulauseke luokiteltiin kategoriaan "Hakuoperaattoreiden puutteellinen tai virheellinen 
käyttö”. Nämä hakulausekkeet olivat siis toimivampia kuin "liian yksinkertaisiksi" luokitellut hakulausekkeet, mistä kertoo myös se, että "liian yksinkertaisen" hakulausekkeen muodostaneet nuoret saivat hakulauseketehtävästä keskimäärin 0,6 pistettä, kun taas puutteellisen/virheellisen hakulausekkeen muodostaneilla nuorilla keskiarvopisteet olivat 1,3 .

Oikeaa vastausta lukuun ottamatta puutteellisen tai virheellisen hakulausekkeen muodostaneet saivat hakulauseketyypittelyssä keskimäärin parhaimmat pisteet. Tämä oli siis toiseksi paras kategoria oikean vastauksen jälkeen. Tähän luokkaan luokiteltiin opettajien ja lukiolaisten hakulausekkeista yli kolmannes, ammattikoululaisten lausekkeista viidesosa ja yläkoululaisten lausekkeista 16 prosenttia (ks. kuva 3). Hakuoperaattorin puutteelliseen tai virheelliseen käyttöön luokitelluista nuorten hakulausekkeista suurin osa (46\%) oli kolmisanaisia ja vain joka kymmenes yksi- tai kaksisanaisia.

ESA taivaankappale Plutosta lapsille (tyttö, yläkoulu)

Avaruusjärjestö ESA Pluto lapsille (opettaja)

Virheellistä hakuoperaattorien käyttöä oli huomattavasti vähemmän kuin hakuoperaattoreiden puutteellista käyttöä. Hakuoperaattoreita virheellisesti käytti kolme prosenttia nuorista ja neljä prosenttia opettajista. Suurin osa hakuoperaattoreiden virheellisestä käytöstä oli väärän hakutermin NOT-poistoja, joita oli nuorilla hieman yli kaksi prosenttia $(\mathrm{N}=78)$.

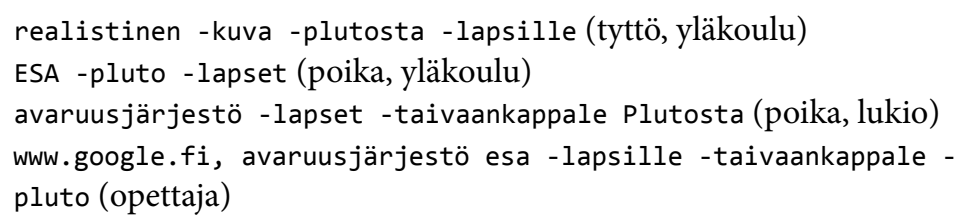

Edelliset sitaatit poistavat mahdollisuuden saada haluttu sivu hakutuloksiin. Miinusmerkillä eli NOT-poistolla olisi tässä tehtävässä tullut poistaa Plutohahmoon liittyvät sivut hakutuloksista (esim. -koira tai -disney). Seuraavaksi eniten hakuoperaattoreiden virheellistä käyttöä esiintyi lainausmerkkien käyttämisenä koko hakulausekkeen ympärillä.

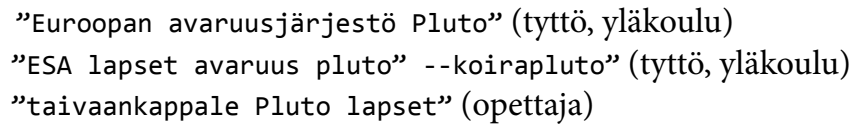

Edellä esitettyjen hakulausekkeiden avulla haluttua sivua ei löydy, koska hakukone yrittää etsiä sivua, jossa olisi koko hakulauseke siinä muodossa kuin se 
on esitetty. Osassa tapauksista hakukone tosin itse korjaa väärän lainausmerkkien käytön, ja ilmoittaa etsivänsä tuloksia hakulausekkeelle ilman lainausmerkkejä.

\section{Verkko-osoitteen muodostaminen hakukenttään}

Yläkoululaisista 17 prosenttia, ammatillisen oppilaitoksen opiskelijoista yhdeksän prosenttia, lukion opiskelijoista kahdeksan prosenttia ja opettajista seitsemän prosenttia yritti muodostaa hakulausekkeen sijasta verkko-osoitetta hakukenttään (ks. kuva 3). Testissä ei saanut käyttää Internetiä, joten verkko-osoite jäi testattujen arvailujen varaan.

http://www.esa.int/lapset/pluto-piirroshahmot (poika, yläkoulu)

http:/esa.int/lapsilletaivaankappaleplutosta.fi (tyttö, yläkoulu)

http://www.planetpluto.com (poika, yläkoulu)

http://www.esa.int/ pluto/children --cartoon (opettaja)

On vaikea sanoa, mitä testattavat ovat ajatelleet muodostaessaan verkkoosoitteita, vaikka tehtävässä pyydettiin laatimaan hakulauseke tietyn tehtävänannon mukaan. Tekaistut verkko-osoitteet eivät luonnollisestikaan vieneet halutulle sivulle, eivät edes Google-hakuun kirjoitettuna.

\section{Hakukoneelle esitetyt kysymykset ja suorat pyynnöt}

Kaikkien kouluasteiden opiskelijoista yhtä suuri osa eli noin kuusi prosenttia ja opettajista joka sadas kirjoitti hakukenttään kysymyksen tai pyynnön hakukoneelle. Kysymykset ja pyynnöt hakukoneelle olivat usein pitkiä ja vain harvoin alle kolmisanaisia.

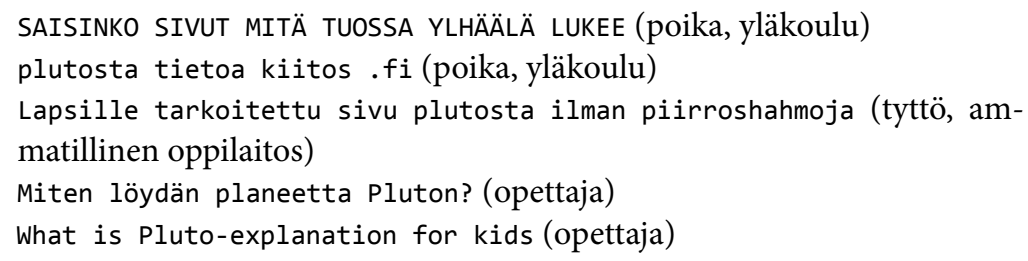

Nuorilla näitä "luonnollisen kielen" hakulausekkeita esiintyi siis kuusi kertaa niin usein kuin opettajilla. Nuorten ikä ei sen sijaan vaikuttanut kysymysten ja pyyntöjen esittämiseen, vaan niitä esiintyi yhtä paljon kaikilla koulutusasteilla. Osa kysymyksistä ja pyynnöistä on esitetty ilmeisesti huumorimielessä, kuten yllä esitetyt kaksi yläkoululaisen pojan hakulauseketta. Myös tehtävään liittymättömistä vastauksista etenkin yläkoulussa ja ammatillisessa oppilaitoksessa opiskelevilla pojilla esiintyi eniten huumorivastauksia, kuten onks se puuhöylä? (poika, yläkoulu) ja oispakaljaa (poika, ammatillinen oppilaitos). 


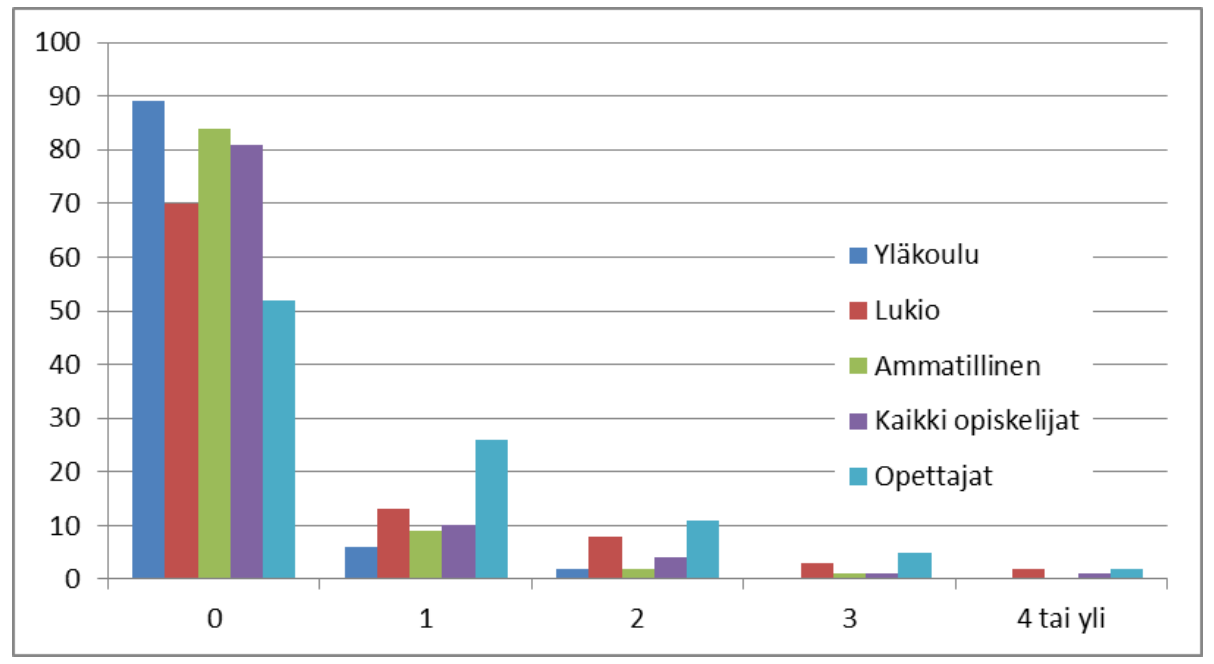

Kuva 4: Hakuoperaattoreiden määrä nuorten ja opettajien hakulausekkeissa (\%).

\section{Hakuoperaattoreiden käyttö}

Tehtävänannon mukaisessa hakulausekkeessa tuli käyttää kahta hakuoperaattoria: site:-operaattoria rajaamaan tulos koskemaan tiettyä Internet-sivustoa (esa.int) sekä “-”-merkkiä rajaamaan Disneyn Pluto-koiran pois hakutuloksista. Aineiston analyysissa luokiteltu hakuoperaattoreiden käyttö ei liittynyt välttämättä tehtävänannossa pyydettyihin seikkoihin tai tehtävässä onnistumiseen, vaan jos hakulausekkeessa oli esimerkiksi lainausmerkit sanan "pluto" ympärillä, se luokiteltiin hakuoperaattoreiden käytöksi. Sen sijaan tapaukset, joissa hakuoperaattorin käyttö olisi johtanut virheellisiin hakutuloksiin, luokiteltiin virheelliseksi hakuoperaattorin käytöksi ja jätettiin pois tarkastelusta.

Hakuoperaattoreiden käyttö oli yllättävän vähäistä etenkin nuorten hakulausekkeissa ottaen huomioon, että niitä nimenomaan pyydettiin käyttämään ja hakuoperaattorit esimerkkeineen selitettiin tehtävänannossa (ks. kuva 1). Ainoastaan viidesosa nuorista käytti hakuoperaattoreita. Opettajista hakuoperaattoreita käytti lähes puolet. Tyttöjen ja poikien välillä ei ollut juurikaan eroja hakuoperaattoreiden käytössä. Lukiolaisista hakuoperaattoreita käytti 30 prosenttia, ammattiopiskelijoista 16 prosenttia ja yläkoululaisista vain joka kymmenes. Lukiolaiset siis käyttivät hakuoperaattoreita kolme kertaa yleisemmin kuin yläkoululaiset. (ks. kuva 4)

Hakuoperaattoreiden määrä nousi nuorilla hakulausekkeessa käytetyn sanamäärän mukaan. Yhden hakusanan hakulausekkeista 97 prosentissa ei ollut käytetty hakuoperaattoreita, kun taas neljän sanan hakulausekkeissa vastaava lu- 
ku oli 67 prosenttia ja yli kuuden sanan hakulausekkeissa 52 prosenttia. Niillä opiskelijoilla, jotka eivät käyttäneet lainkaan hakuoperaattoreita, keskiarvopisteet olivat 0,7 , yhdellä hakuoperaattorilla sai keskimäärin 1,4 pistettä ja kahdella hakuoperaattorilla keskimäärin kaksi pistettä.

Oikean vastauksen antaneista nuorista luonnollisesti kaikki käyttivät vähintään kahta hakuoperaattoria. Liian yksinkertaisen hakulausekkeen muodostaneista nuorista vain kuusi prosenttia käytti hakulausekkeissaan hakuoperaattoreita. Hakuoperaattoreiden virheellinen tai puutteellinen käyttö koski lähinnä hakuoperaattoreiden puutteellista käyttöä. Noin puolet nuorten tähän kategoriaan luokitelluista hakulausekkeista oli esitetty täysin ilman hakuoperaattoreita ja viidenneksessä niistä oli vain yksi hakuoperaattori oikeaan vastaukseen vaaditun kahden hakuoperaattorin sijaan. Suurin osa verkko-osoitteen muodostamisyrityksistä oli tehty ilman hakuoperaattoreita, mutta osa oli laittanut näihinkin jonkin hakuoperaattorin. Kysymykset tai pyynnöt hakukoneelle esitettiin lähes aina ilman hakuoperaattoria, kuten luonnollisen kielen hakulausekkeisiin hyvin sopiikin.

\section{Pohdinta ja johtopäätökset}

Tiedonhakutehtävässä pyydetyn tarkoituksenmukaisen ja kattavan hakulausekkeen hakuoperaattoreineen osasi muodostaa vain pari prosenttia nuorista ja seitsemän prosenttia opettajista. Opettajat ja lukiolaiset saivat keskimäärin lähes kolmasosan tehtävän maksimipisteistä, kun yläkoululaisten ja ammatillisen oppilaitoksen opiskelijoiden pisteet olivat vain hieman yli kuudesosa maksimipisteistä. Nuorten osalta sukupuolella ei ollut hakulauseketehtävässä merkitystä; sen sijaan miesopettajat menestyivät naisopettajia tilastollisesti merkitsevästi paremmin. Kaikenikäiset opettajat pärjäsivät hakulausekkeen muodostamisessa keskimäärin kaikenikäisiä nuoria paremmin, mutta lukiolaisiin verrattuna paremmin pärjäsivät vain alle 45 -vuotiaat opettajat.

Suurin osa nuorten ja opettajien hakulausekkeista oli liian yksinkertaisia. Niissä oli vain yksi tai kaksi sanaa eikä niissä ollut tehtävänannosta huolimatta käytetty lainkaan hakuoperaattoreita. Näissä hakulausekkeissa huomioitavaa on etenkin niiden laajuus; nuorten hakulausekkeissa saattoi olla vain yksi paljon laajempaa informaatiokokonaisuutta koskeva sana, kuten tähtitiede tai avaruus, eikä mitään muuta. Jos nämä nuoret lähtevät etsimään tietoa esimerkiksi koulutehtäviinsä yhtä laajalla skaalalla, tarvittavan informaation löytämiseen saattaa kulua huomattavasti aikaa, mikäli sitä lopultakaan löytyy. Kiinnostavaa on myös se, että hakuoperaattorirajauksen sijaan nuoret saattoivat vain kertoa hakukoneelle suoraan mitä halusivat, kuten Pluto ei koira. Valitettavasti esi- 
merkkihakulauseke johtaa päinvastaiseen lopputulokseen ja hakutulokset käsittelevät juurikin Pluto-koiraa.

Pieni osa $(\mathrm{N}=78)$ testattavista käytti NOT-operaattoria väärin ja poisti sillä hakulausekkeessa tarvittavia hakusanoja. Näin ollen he eivät tällä hakulausekkeella olisi mitenkään pystyneet löytämään haluttua sivua. Moni nuori poisti --merkillä kaikki tarvittavat hakusanat hakulausekkeestaan. Testattavat ovat ehkä hahmottaneet --merkit ranskalaisina viivoina, eivätkä ole ymmärtäneet, että Google-haussa miinusmerkki poistaa sen jälkeiseen sanaan liittyvät dokumentit tai sivustot kokonaan hakutuloksista. Näin ollen he eivät myöskään ole lukeneet tehtävänantoa huolella (ks. kuva 1). Erikoista oli, että yläkoululaisista lähes viidennes ja toisen asteen opiskelijoista sekä opettajista hieman alle joka kymmenes muodosti hakulausekkeen sijaan verkko-osoitteen hakukenttään. Verkkoosoitteet olivat täysin keksittyjä, koska testattavat eivät saaneet käyttää Internetiä testin aikana, josta haluttu verkko-osoite olisi saattanut löytyä. Voidaanko tästä päätellä, että käsitteiden verkko-osoite ja hakulauseke erot ovat osalle testattavista vieraita? Verkko-osoitteen laatijoita oli sekä nuorissa että opettajista jopa enemmän kuin kysymyksen tai pyynnön hakukoneelle esittäneitä, vaikka etenkin nuorten osalta olisi voinut kuvitella asian olevan päinvastoin. Esimerkiksi Kammererin ja Bohnackerin (2012) tutkimuksessa suurin osa 8-10-vuotiaista käytti hakulausekkeissaan ns. luonnollista kieltä ja kysyi hakukoneelta esimerkiksi kysymyksiä. Tässä tosin saattaa olla erona se, että Kammererin ja Bohnackerin tutkimuksessa testattiin nuorten ja opettajien sijaan lapsia, eikä tehtävänannoissa pyydetty erikseen käyttämään hakuoperaattoreita.

Hakuoperaattoreiden käyttö hakulausekkeissa oli vähäistä siihen nähden, että niitä nimenomaan pyydettiin käyttämään tehtävänannossa. Vain viidesosa kaikista nuorista käytti hakuoperaattoreita, opettajista sentään puolet. Lukiolaiset käyttivät hakuoperaattoreita kolme kertaa yleisemmin kuin yläkoululaiset, joista vain joka kymmenes käytti hakulausekkeessaan hakuoperaattoria. Tästä voidaan päätellä, että hakuoperaattoreiden käyttö on tutumpaa opettajille kuin nuorille. Nuorilla, etenkään yläkoululaisilla, ei luultavasti ole yhtä paljon kokemusta hakukoneiden käytöstä kuin opettajilla, eivätkä he ehkä ole koskaan joutuneet tekemään vaativampia hakulausekkeita. Nuoret saattavat selvitä informaationhakutarpeistaan hyvin yksinkertaisilla hauilla, ja hakuoperaattoreiden käyttö voi olla heille vierasta, ellei niitä ole koulussa erikseen opetettu. Nykyään hakukoneet osaavat korjata kirjoitusvirheitä ja vääriä hakuoperaattoreiden käyttöjä, joten helpoissa informaationhakutilanteissa pärjää hyvin yksinkertaisillakin hakulausekkeilla.

Jatkossa hakulauseketehtävien tehtävänanto tulisi suunnitella tarkemmin. Nyt testistä saadut pisteet painottuvat hakuoperaattorien käytön hallitsemiseen. Tyypilliset hakukoneiden arkikäyttäjät tarvitsevat hakuoperaattoreiden käyttöä 
hauissaan vain hyvin harvoin, jos koskaan. Näin ollen se, että 2/3 pisteistä riippuu juuri hakuoperaattoreiden oikeasta käytöstä, ei mittaa olennaisia arjessa tarvittavia tiedonhakutaitoja. Lisäksi hakulauseketehtävässä saattoi pärjätä pelkästään hyvällä lukutaidolla, keskittymisellä ja päättelytaidoilla: Koska hakuoperaattoriesimerkit sekä haun pääkäsitteet oli annettu tehtävässä, testissä pärjääminen riippui suurelta osin testiin osallistuneiden luetun ymmärtämisen taidoista sekä taidosta soveltaa lukemaansa informaatiota käytännössä. Lisäksi tarvittiin kärsivällisyyttä lukea tehtävänanto ja esimerkit huolellisesti ennen vastaamista. Parhaiten tiedonhakutaitoa voisi mitata aidoilla tiedonhakutehtävillä, joissa testattavien tulisi etsiä jokin informaatio Internetistä ja kirjoittaa löytämänsä vastaus (tai liittää etsittävä dokumentti) vastauskenttään. Tällaisia tehtäviä on kuitenkin tässä artikkelissa käytettyä menetelmää hankalampi toteuttaa suurelle tutkimusjoukolle siten, että testattavien hakulausekkeet ja erilaiset hakukokeilut jäisivät tutkijalle tutkimusmateriaaliksi.

Tiedonhallinnan osaaminen digitaalisissa konteksteissa korostuu kautta uusien opetussuunnitelmien (Opetushallitus, 2014, 2015). Tiedonhaun opettaminen kouluissa edellyttää opettajilta hyvää informaatiolukutaitoa ja kykyä ohjata oppilaiden tiedonhakutilanteita. Vaikka opettajat pärjäsivätkin hakulausekkeen muodostamisessa nuoria paremmin, vain alle kymmenesosa opettajista antoi täysin tai lähes oikean vastauksen tehtävään. Lisäksi opettajat tekivät hakulausekkeissaan samanlaisia virheitä kuin nuoretkin. Tiedonhaun edellyttämä osaaminen on luonteeltaan monimutkaisia, eikä tarvittavia taitoja hankita opettelematta (Anzera \& Comunello, 2014). Tutkimuksen perusteella nuorille tulisi opettaa kouluissa hakuoperaattoreiden käyttöä ja tarkoituksenmukaisen hakulausekkeen muodostamista erilaisissa tiedonhakutilanteissa. Samalla tulisi varmistaa, että opettajat osaavat nämä taidot, jotta he voivat opettaa niitä oppilailleen. 


\section{Lähteet}

Anzera, G., \& Comunello, F. (2014). Toward digital inclusion: digital divides and new media literacies. Teoksessa S. Baum \& A. Mahizhnan (toim.), E-Governance and Social Inclusion: Concepts and Cases (ss. 62-82). Hershey, PA: IGI Global. http://doi.org/10.4018/978-14666-6106-6.ch005 (luettu 17.2.2018)

Google. (2014). Hakuoperaattorit - verkkohakuohjeet. http://web.archive.org/web/ 20140123004035/https://support.google.com/websearch/answer/136861?hl=fi (luettu 17.2.2018)

Hargittai, E., \& Shafer, S. (2006). Differences in actual and perceived online skills: the role of gender. Social Science Quarterly, 87(2), 432-448. https://doi.org/10.1111/j.1540-6237.2006. 00389.x

Henry, L. A. (2006). SEARCHing for an answer: the critical role of new literacies while reading on the Internet. The Reading Teacher, 59(7), 614-627. https://doi.org/10.1598/RT.59.7.1

Järvelin, K., \& Sormunen, E. (2010). Tiedon tallennus ja haku. Teoksessa S. Serola (toim.), Ote informaatiosta : johdatus informaatiotutkimukseen ja interaktiiviseen mediaan (ss. 155-210). Helsinki: BTJ.

Jean, B. S., Subramaniam, M., Taylor, N. G., Follman, R., Kodama, C., \& Casciotti, D. (2015). The influence of positive hypothesis testing on youths' online health-related information seeking. New Library World, 116(3/4), 136-154. https://doi.org/10.1108/NLW-07-2014-0084

Kaarakainen, M.-T., \& Saikkonen, L. (2015). Tiedonhakutaidot testissä - nuorten osaaminen hakukanavan valinnassa, hakulausekkeen muotoilussa ja hakutulosten arvioinnissa. Informaatiotutkimus, 34(4). https://journal.fi/inf/article/view/53484 (luettu 17.2.2018)

Kaarakainen, M.-T., \& Saikkonen, L. (2017). Peruskoulun ja lukion opettajien tiedonhakutaidot. Kasvatus, 48(1), 35-49.

Kammerer, Y., \& Bohnacker, M. (2012). Children's web search with Google: the effectiveness of natural language queries. Teoksessa Proceedings of the 11th International Conference on Interaction Design and Children (ss. 184-187). New York, NY, USA: ACM. https://doi.org/10. $1145 / 2307096.2307121$

Kiili, C. (2012). Online reading as an individual and social practice. Jyväskylä studies in education, psychology and social research 441. http://urn. fi/URN: ISBN: 978-951-39-4795-8 (luettu 17.2.2018)

Kiili, C., Laurinen, L., \& Marttunen, M. (2008). Students evaluating Internet sources: from versatile evaluators to uncritical readers. Journal of Educational Computing Research, 39(1), 75-95. http://urn.fi/URN:NBN: fi: jyu-201604192239 (luettu 17.2.2018)

Kiili, C., Laurinen, L., \& Marttunen, M. (2009). Skillful Internet reader is metacognitively competent. Teoksessa L. Tan Wee Hin \& R. Subramaniam (toim.), Handbook of Research on New Media Literacy at the K-12 Level: Issues and Challenges (ss. 654-668). http://doi.org/10.4018/ 978-1-60566-120-9.chø41 (luettu 17.2.2018)

Knight, S. A., \& Spink, A. (2008). Toward a web search information behavior model. Teoksessa Web Search (ss. 209-234). Springer, Berlin, Heidelberg. https ://doi .org/10.1007/978- 3-54075829-7_12

Large, A., Beheshti, J., \& Rahman, T. (2002). Gender differences in collaborative web searching behavior: an elementary school study. Information Processing \& Management, 38(3), 427-443. https://doi.org/10.1016/s0306-4573(01)00034-6

Leu, D. J., Kinzer, C. K., Coiro, J., \& Cammack, D. W. (2004). Toward a theory of new literacies emerging from Internet and other information and communication technologies. Teoksessa R. B. Ruddell \& N. J. Unrau (toim.), Theoretical Models and Processes of Reading (ss. 15701613). Newark, DE: International Reading Association. 
Muhonen, M., Kaarakainen, M.-T., \& Savela, J. (2015). Opettajien teknologiataidot oppilaiden tulevaisuuden taitojen (epä)tasa-arvoisuuden edistäjinä? Teoksessa J. Viteli \& A. Östman (toim.), Tuovi 13: Interaktiivinen tekniikka koulutuksessa 2015 -konferenssin tutkijatapaamisen artikkelit. Tampere: Tampereen yliopisto. http://urn.fi/URN: ISBN: 978-951-44-9909-8 (luettu 17.2.2018)

OECD (toim.). (2015). Students, computers and learning: making the connection. Paris: OECD. http://doi.org/10.1787/9789264239555-en (luettu 18.2.2018)

Ojaranta, A. (2011). Opettajien ja kirjastonhoitajien käsitykset informaatiolukutaidosta ja tiedonhaun opetuksesta koulussa. Informaatiotutkimus, 30(3-4). https://journal.fi/inf/article/ view/4702 (luettu 17.2.2018)

Opetushallitus. (2014). Perusopetuksen opetussuunnitelman perusteet 2014 (4. p.). Helsinki: Opetushallitus. https://web.archive.org/web/20170628050502/http: //www.oph.fi/download/163777_perusopetuksen_opetussuunnitelman_perusteet_2014.pdf

Opetushallitus. (2015). Lukion opetussuunnitelman perusteet 2015. Helsinki: Opetushallitus. https://web.archive.org/web/20170628050502/http://www.oph.fi/download/163777_ perusopetuksen_opetussuunnitelman_perusteet_2014.pdf

Tanni, M. (2012). Opettajaharjoittelijoiden tiedonhankinta ja käsitykset informaatiolukutaidon opettamisesta. Informaatiotutkimus, 31(3). https://journal.fi/inf/article/view/7117 (luettu 17.2.2018)

van Deursen, A. J. A. M., Görzig, A., van Delzen, M., Perik, H. T. M., \& Stegeman, A. G. (2014). Primary school children's Internet skills: a report on performance tests of operational, formal, information, and strategic Internet skills. International Journal of Communication, 8, 13431366. http://eprints.lse.ac.uk/57211/ (luettu 17.2.2018)

van Deursen, A. J. A. M., \& van Diepen, S. (2013). Information and strategic Internet skills of secondary students: a performance test. Computers \& Education, 63, 218-226. https://doi. org/10.1016/j. compedu. 2012.12.007

Walraven, A., Brand-Gruwel, S., \& Boshuizen, H. P. A. (2008). Information-problem solving: a review of problems students encounter and instructional solutions. Computers in Human Behavior, 24(3), 623-648. https://doi.org/10.1016/j.chb.2007.01.030 